\title{
Induction of Autolysis in Streptococcus faecium
}

\author{
By M. EGIDIA CARVALHO,* M. HELENA GONÇALVES \\ AND MANUEL T. SILVA \\ Instituto de Ciências Biomédicas 'Abel Salazar', Largo da Escola Médica, 4000 Porto \\ and Centro de Citologia Experimental da Universidade do Porto, Porto, Portugal
}

(Received 28 August 1986: revised 18 November 1986)

\begin{abstract}
Autolysis of exponential-phase Streptococcus faecium cells was promoted by pretreating the bacteria (freezing-thawing; $-70^{\circ} \mathrm{C}$ ) in Tris buffer, followed by incubation at $37^{\circ} \mathrm{C}$ in the same buffer. The effect was dependent on Tris concentration. The pretreatment provoked ultrastructurally visible damage with extensive loss of $\mathrm{K}^{+}$and leakage of UV-absorbing components. No autolysis was observed when the bacteria frozen-thawed in Tris were incubated in the presence of the autolysin inhibitor $N$-bromosuccinimide nor when they had been grown in the presence of chloramphenicol or tetracycline. Furthermore, two autolyticdefective mutants, EC3I and EC78, isolated from $S$. faecium, did not autolyse when frozenthawed and incubated in Tris. Freezing-thawing in Tris, however, imparted extensive cell damage to the mutants and to the antibiotic-treated bacteria as well as considerable leakage of $\mathrm{K}^{+}$and UV-absorbing materials. These observations indicate that the lysis of $S$. faecium reported above is due to the activity of the endogenous bacterial autolysin. Induction of autolysis of $S$. faecium by freezing-thawing was also observed, although to a lesser extent, when Tris was replaced by imidazole.
\end{abstract}

\section{INTRODUCTION}

Bacterial autolysins are generally found in exponential-phase cultures but to a lesser extent in stationary-phase cultures, suggesting a role in the overall process of bacterial growth (Rogers, 1979; Shockman et al., 1967). Bacterial autolysins have been implicated in many important biological phenomena (Pooley, 1976; Ranhand et al., 1971; Rogers, 1979; Pooley \& Karamata, 1984). Several factors influence the occurrence and extent of bacterial autolysis including growth conditions, osmotic environment and pH of the medium (Shockman, 1965; Carson \& DaneoMoore, 1980).

Streptococcus faecium ATCC 9790 generally does not lyse spontaneously, some kind of induction being necessary to bring about rapid and extensive autolysis. We have previously shown that fresh $S$. faecium cells do not lyse either in phosphate or Tris buffer $(\mathrm{pH} \mathrm{8.0)}$; however, when they are frozen-thawed $\left(-70^{\circ} \mathrm{C}\right)$ in Tris buffer before incubation in the same buffer some autolysis is obtained (Carvalho et al., 1984). This observation prompted us to study in more detail the induction of autolysis by the freezing-thawing of cells in Tris, imidazole and phosphate buffers at the optimum $\mathrm{pH}$ for the activity of $S$. faecium autolysin (pH 6.8) (Shockman et al., 1967; Sayare et al., 1972).

\section{METHODS}

Bacterial strains. Most of the experiments were done with Streptococcus faecium ATCC 9790. Two mutants, EC31 and EC78, were isolated from $S$. faecium by mutation with ethylmethane sulphonate and characterized as autolytic-defective as described by Pooley et al. (1972).

Abbreviations: CAM, chloramphenicol; TC, tetracycline; NBS, $N$-bromosuccinimide. 
Growth conditions. The wild-type strain of $S$. faecium and the two autolytic-defective mutants were grown at $37^{\circ} \mathrm{C}$ in medium T [ $1 \%$, w/v, tryptone (Difco) $0 \cdot 5 \%$, w/v, yeast extract (Difco) $; 0 \cdot 25 \%, w / v, \mathrm{~K}_{2} \mathrm{HPO}_{4} ; 1 \%$, w/v, glucose, pH 7.2] (Carvalho et al., 1984). In some experiments, $30 \mathrm{~min}$ before the harvest of cells, chloramphenicol (CAM; $10 \mu \mathrm{g} \mathrm{ml}^{-1}$; Sigma) or tetracycline (TC; $0.5 \mu \mathrm{g} \mathrm{ml}^{-1}$; Sigma) was added to the cultures. Growth was followed by measuring the $\mathrm{OD}_{520}$ in a Bausch \& Lomb Spectronic 20 spectrophotometer.

Autolysis assays. Early exponential-phase cells $\left(\mathrm{OD}_{520} \quad 0.5\right)$ were harvested by centrifugation for $10 \mathrm{~min}$ at $15000 \mathrm{~g}$, and washed and resuspended in the appropriate lysis buffers or in medium $\mathrm{T}$ without $\mathrm{K}_{2} \mathrm{HPO}_{4}$. Some samples were frozen as concentrated suspensions at $-70^{\circ} \mathrm{C}$ in a deep-freezer before use. Suspensions $(20 \mathrm{ml}$; $7.2 \times 10^{8} \mathrm{cells} \mathrm{ml}^{-1}$ ) of freshly grown cells or frozen cells thawed at room temperature were transferred to $250 \mathrm{ml}$ flasks and incubated for $120 \mathrm{~min}$ at $37^{\circ} \mathrm{C}$ in the following buffers: $0.01-0.5 \mathrm{M}-\mathrm{Tris} / \mathrm{HCl}, \mathrm{pH} 6.8 ; 0.01-0.4 \mathrm{M}-$ imidazole (grade III, Sigma)/HCl, pH 6.8;0.01-0.5 M-NaH $\mathrm{PO}_{4} / \mathrm{Na}_{2} \mathrm{HPO}_{4}$, pH 6.8;0.01-0.5 $\mathrm{M}-\mathrm{Na}_{2} \mathrm{HPO}_{4} /$ $\mathrm{KH}_{2} \mathrm{PO}_{4}$, pH 6.8. Where indicated, $N$-bromosuccinimide (NBS, Sigma) was added to the lysis buffer at a inal concentration of $1 \mathrm{mM}$. In some experiments, $\mathrm{MgSO}_{4}$ was added to the lysis buffer at a final concentration of 10 or $100 \mathrm{~mm}$. In all cases, the optical density of the suspensions was followed by a Bausch \& Lomb Spectronic 710 spectrophotometer.

$\mathrm{K}^{+}$efflux assays. The efflux of $\mathrm{K}^{+}$was determined by assaying filtrates obtained in less than $30 \mathrm{~s}$ with membrane filters (type HA, pore size $0.45 \mu \mathrm{m}$, Millipore Corp.). The values are given as a percentage: a $100 \%$ value corresponds to the $\mathrm{K}^{+}$leaked from bacteria boiled for $30 \mathrm{~min}$. $\mathrm{K}^{+}$was assayed with an EEL flame photometer, model 150.

Leakage of UV-absorbing materials. Using filtrates obtained as indicated above, the amount of intracellular material that absorbs at 260 and $280 \mathrm{~nm}$, respectively, was determined with a UV-visible recording spectrophotometer (UV-260 Shimadzu) in samples of fresh or frozen-thawed bacterial suspensions in various buffers as indicated below.

Electron microscopy. Bacteria for ultrastructural studies were collected both before incubation in the autolysis buffers and at intervals during incubation. In both cases fresh and frozen-thawed cells were studied. Fixation was by adding stock $25 \%(\mathrm{w} / \mathrm{v})$ glutaraldehyde (TAAB Laboratories) directly to the samples to a final concentration of $2.5 \%(\mathrm{w} / \mathrm{v})$. In some experiments, frozen cells were thawed, centrifuged and resuspended in $0.05 \mathrm{M}$-sodium

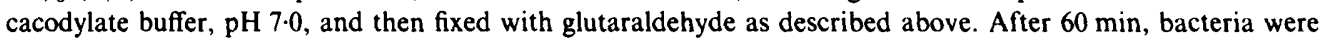
pelleted by centrifugation and post-fixed with $1.0 \%$ (w/v) $\mathrm{OsO}_{4}$ (Ryter \& Kellenberger, 1958) followed $16 \mathrm{~h}$ later by $1.0 \%(\mathrm{w} / \mathrm{v})$ aqueous uranyl acetate (Silva et al., 1971). The fixed pellets were processed for ultramicrotomy by embedding in Epon 812 (Luft, 1961). The ultrathin sections were contrasted with uranyl acetate (aqueous saturated solution) for $50 \mathrm{~s}$ followed by lead citrate (Venable \& Coggeshall, 1965) for $2 \mathrm{~min}$; they were observed under a Siemens Elmiskop IA transmission electron microscope.

Characterization of membranes isolated from autolysed $S$. faecium cells. Membrane vesicles were isolated from $S$. faecium suspensions that had been allowed to autolyse until a constant $\mathrm{OD}_{520}$ value was reached. The final lysate was centrifuged at $800 \mathrm{~g}$ for $10 \mathrm{~min}$ to separate cell debris, and the supernatant was spun at $30000 \mathrm{~g}$ for $30 \mathrm{~min}$ to pellet the membrane vesicles. These vesicles were washed once in the autolysis buffer. The protein content of the membrane vesicles was assayed by the Lowry method, using lysozyme (grade 1, Sigma) as standard. The SDSPAGE protein profile of the isolated membranes was as described by Carvalho et al. (1984). The ultrastructure of these membranes was studied by the methods indicated above. Tracings of membrane profiles were made on photographic negatives with a Joyce-Loebl Mk. III CS microdensitometer, set to an arm ratio of $50 \times$ and a slit width of $0.5 \mathrm{~nm}$.

\section{RESULTS}

\section{Effect of freezing-thawing in different buffers on $S$. faecium autolysis}

When exponential-phase $S$. faecium cells were suspended in $0.01-0.5 \mathrm{M}-\mathrm{Tris}$ buffer, no lysis was observed during $120 \mathrm{~min}$ of incubation (Fig. 1), and the ultrastructural study showed unaltered cells. However, lysis was efficiently promoted when bacteria were frozen and thawed in Tris buffer before incubation (Fig. 1). As shown below, the lysis was due to the activity of the S. faecium autolysin.

The rate of autolysis of frozen cells was dependent on Tris concentration and was maximal at $0 \cdot 1 \mathrm{M}$ (Fig. 1). Samples for electron microscopy collected immediately after the freezing-thawing of bacteria in $0.1 \mathrm{M}$-Tris buffer showed damaged bacteria (Fig. $2 a$ ). Such damage is due to the direct effect of Tris on bacteria, since similar ultrastructural alterations were seen when bacteria frozen in Tris buffer were then fixed with glutaraldehyde in cacodylate (not shown). On the other hand, the $\mathrm{K}^{+}$efflux from $S$. faecium cells frozen in $0.1 \mathrm{M}$-Tris buffer was much increased when compared with the $\mathrm{K}^{+}$efflux from fresh bacteria (Fig. 3). 


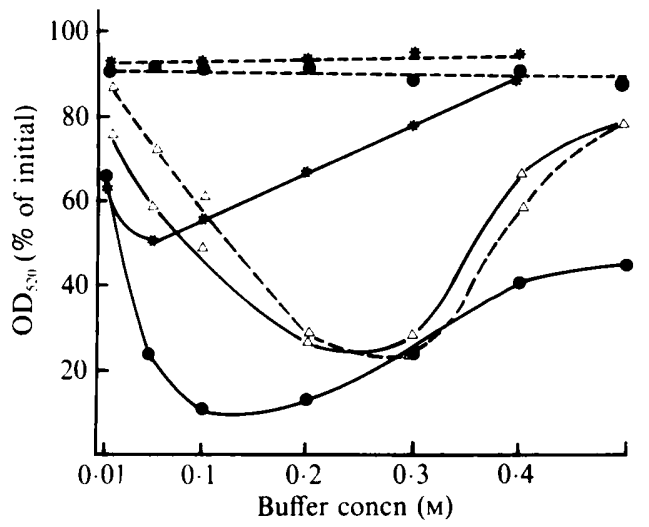

Fig. 1. Effect of freezing-thawing and of several buffers on the autolysis of $S$. faecium. Exponentialphase cells, fresh (----) or previously frozen-thawed $(-)$, were suspended in sodium phosphate, Tris or imidazole buffers, $\mathrm{pH} \mathrm{6.8.} \mathrm{Autolysis} \mathrm{was} \mathrm{assayed} \mathrm{by} \mathrm{the} \mathrm{loss} \mathrm{of} \mathrm{optical} \mathrm{density} \mathrm{of} \mathrm{cell} \mathrm{suspensions}$ $\left(7.2 \times 10^{8}\right.$ cells $\left.\mathrm{ml}^{-1}\right)$ during $120 \mathrm{~min}$ incubation at $37^{\circ} \mathrm{C}$. $\triangle$, Sodium phosphate buffer; $O$, Tris $/ \mathrm{HCl}$ buffer, *, imidazole/ $\mathrm{HCl}$ buffer.

Table 1. Cellular autolysis of S. faecium

Exponential-phase cells were washed and frozen-thawed in the indicated buffers or in medium $\mathrm{T}$ without $\mathrm{K}_{2} \mathrm{HPO}_{4}$. Where indicated, after thawing the bacteria were centrifuged at $15000 \mathrm{~g}$ for $5 \mathrm{~min}$ to remove the buffers used for freezing-thawing and resuspended in the incubation buffers. Autolysis was assayed by the decrease in optical density of cell suspensions $\left(7.2 \times 10^{8}\right.$ bacteria $\left.\mathrm{ml}^{-1}\right)$ during $120 \mathrm{~min}$ incubation at $37^{\circ} \mathrm{C}$. The results are expressed as a percentage of the initial optical density. ND, Not determined.

\begin{tabular}{lcccc} 
& \multicolumn{3}{c}{ Incubation buffer } \\
\cline { 2 - 4 } Freezing-thawing buffer & $\begin{array}{c}\text { Tris } \\
(0 \cdot 1 \mathrm{M})\end{array}$ & $\begin{array}{c}\text { Sodium/potassium } \\
(0.01 \mathrm{M})\end{array}$ & $\begin{array}{c}(0 \cdot 3 \mathrm{M}) \\
\text { ris }(0 \cdot 1 \mathrm{M})\end{array}$ \\
Sodium/potassium phosphate & $(0 \cdot 01 \mathrm{M})$ & 11 & 18 & 41 \\
Medium T & $(0 \cdot 3 \mathrm{M})$ & 64 & 78 & 43 \\
No freezing-thawing & & 40 & 28 & 41 \\
& & 90 & $\mathrm{ND}$ & 41 \\
& 90 & 86 & 23
\end{tabular}

Imidazole buffer yielded results similar to those obtained with Tris (Fig. 1). However, the rate of autolysis of bacteria frozen in imidazole buffer was lower than in Tris buffer and was maximal at a concentration of $0.05 \mathrm{M}$. Ultrathin sections of cells collected immediately after freezing thawing in $0.05 \mathrm{M}$ - or $0.4 \mathrm{M}$-imidazole buffer also showed damaged bacteria, and for $0.05 \mathrm{M}$ buffer the $\mathrm{K}^{+}$efflux was much increased when compared with the $\mathrm{K}^{+}$efflux from unfrozen bacteria suspended in the same buffer (Fig. 3). Cells frozen-thawed in $0.4 \mathrm{M}$-Tris or imidazole buffers lost all their intracellular $\mathrm{K}^{+}$(not shown).

Additional experiments (Table 1) showed that: (i) freezing-thawing in $0.1 \mathrm{M}$-Tris resulted in activation of the $S$. faecium autolysin, especially when the cells were incubated in $0 \cdot 1 \mathrm{M}$-Tris or in $0.01 \mathrm{M}$-sodium/potassium phosphate; (ii) previous freezing-thawing in phosphate buffer does not increase the rate of autolysis of fresh bacteria in the same buffer (Fig. 1); (iii) freezingthawing in broth does not promote the activation of the autolysin, since no lysis occurred when cells so treated were incubated in $0.1 \mathrm{M}$-Tris buffer. Interestingly, freezing-thawing in phosphate (Fig. $2 b$ ) or broth did not induce ultrastructural alterations (not shown) and resulted in a moderate leakage of $\mathrm{K}^{+}$(Fig. 3) and UV-absorbing material (not shown). 

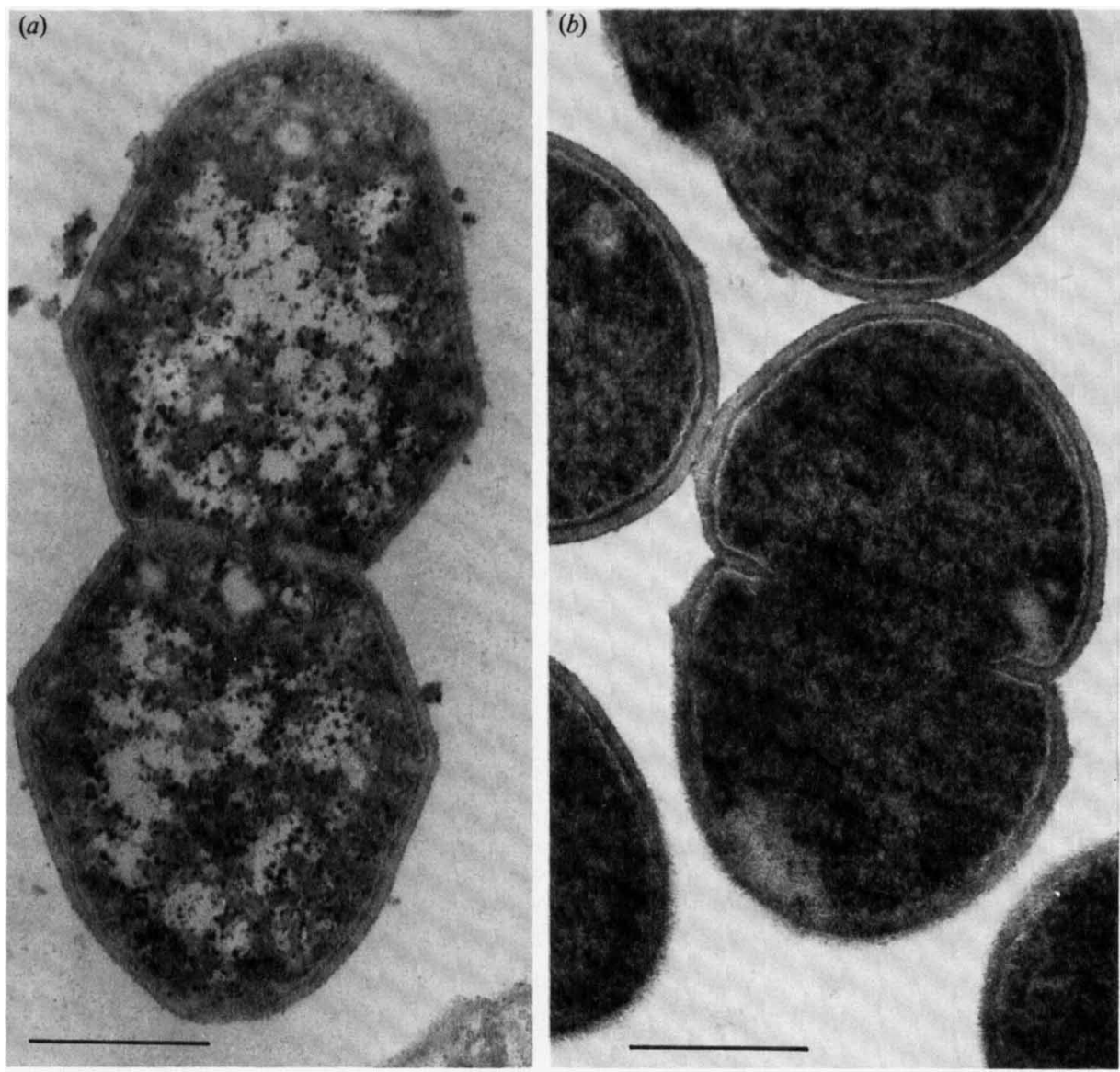

Fig. 2. Ultrastructure of $S$. faecium collected immediately after freezing-thawing $\left(-70^{\circ} \mathrm{C}\right)$ in $(a) 0 \cdot 1 \mathrm{M}-$ Tris buffer, pH 6.8 - note the altered cell contents and absence of ribosomes - or $(b) 0.3 \mathrm{M}$-sodium phosphate buffer, pH 6.8 - note that cells show a normal ultrastructure, namely intact cell walls and ribosomes. Bars, $400 \mathrm{~nm}$.

Role of $S$. faecium autolysin in the lytic process

The exposure of exponential-phase cultures of $S$. faecium to CAM $\left(10 \mu \mathrm{g} \mathrm{ml}^{-1}\right)$ or TC $\left(0.5 \mu \mathrm{g} \mathrm{ml}^{-1}\right)$ extensively inhibited autolysis of fresh or frozen-thawed bacteria. Freezingthawing of CAM-treated cells suspended in Tris resulted, however, in ultrastructural damage similar to that with untreated cells, and in extensive leakage of $\mathrm{K}^{+}$and $\mathrm{UV}$-absorbing materials (not shown). Moreover NBS, when added at final concentration of $1 \mathrm{mM}$, completely inhibited cellular autolysis of cells in Tris buffer (not shown).

Two autolytic-defective mutants of $S$. faecium, EC31 and EC78, showed a much-decreased capacity for cellular autolysis after freezing-thawing in Tris, a treatment that resulted in extensive cell damage (Fig. 4) and significant efflux of $\mathrm{K}^{+}$and $\mathrm{UV}$-absorbing materials (not shown).

\section{Influence of $\mathrm{Mg}^{2+}$}

The presence of $10 \mathrm{~mm}-\mathrm{Mg}^{2+}$ in $0 \cdot 1 \mathrm{M}$-Tris buffer during freezing-thawing and incubation partially decreased the rate and extent of autolysis of frozen cells, as well as the leakage of UVabsorbing materials, but did not prevent the high $\mathrm{K}^{+}$efflux (Fig. 3). However, $10 \mathrm{~mm}-\mathrm{Mg}^{2+}$ prevented in part the cytoplasmic membrane damage since after $120 \mathrm{~min}$ incubation intact 


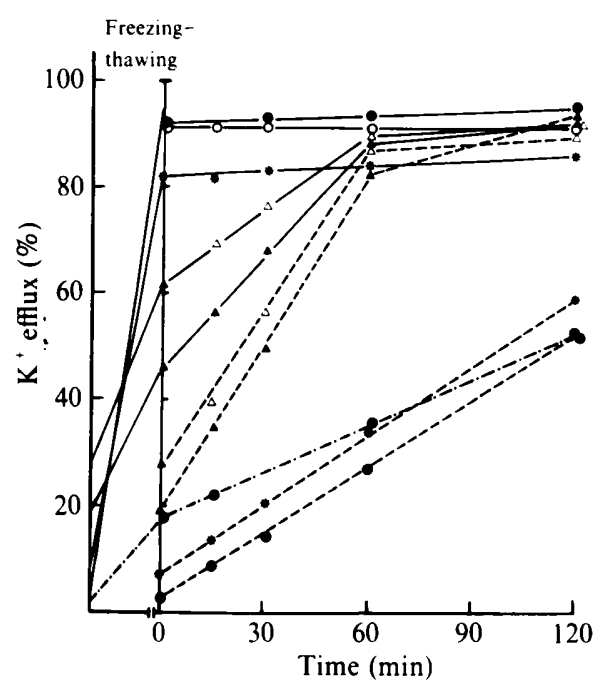

Fig. 3. $\mathrm{K}^{+}$efflux after freezing-thawing and/or during incubation of $S$. faecium in various conditions. Unfrozen cells $(---)$ or cells frozen $\left(-70^{\circ} \mathrm{C}\right)$ in Tris, phosphate or imidazole buffers $(-)$ or in medium T without $\mathrm{K}_{2} \mathrm{HPO}_{4}(-\cdot-\cdot)$ were resuspended $\left(7.2 \times 10^{8}\right.$ cells $\left.\mathrm{ml}^{-1}\right)$ and incubated at $37^{\circ} \mathrm{C}$ in Tris, phosphate or imidazole buffers. Filtrates of samples collected after freezing-thawing or during incubation were assayed for $\mathrm{K}^{+}$. The $\mathrm{K}^{+}$content of filtrates of each suspension boiled for 30 min was normalized to $100 \%$., $0.1 \mathrm{M}$-Tris; $\mathrm{O}, 0.1 \mathrm{M}$-Tris and $10 \mathrm{mM}-\mathrm{MgSO}_{4} ; *, 0.05 \mathrm{M}$ imidazole; $\Delta, 0.2 \mathrm{M}$, $\triangle, 0.3 \mathrm{M}$-sodium phosphate buffer.

protoplasts were visible (not shown). Furthermore, autolysis was strongly inhibited when $100 \mathrm{mM}-\mathrm{Mg}^{2+}$ was added at the beginning of the autolytic process, or partially inhibited when it was added $30 \mathrm{~min}$ later to the autolysing cells [in the first case the final $\mathrm{OD}_{520}$ value was $74 \%$, and in the second case $57 \%$, of the initial value, instead of $11 \%$ when $\mathbf{M g}^{2+}$ was not present (Fig. 1)]; in both cases the ultrastructural studies, in accordance with the optical density data, revealed intact protoplasts and many unlysed cells, some of them with normal cell walls (not shown).

\section{Characteristics of membranes isolated in Tris or phosphate buffers}

Thin sections of membranes isolated from bacteria frozen and incubated in $0.05 \mathrm{M}$-Tris buffer (Fig. $5 a$ ) showed a loose triple-layered structure with a thickness of $5.68 \pm 0.43 \mathrm{~nm}$ (peak-topeak distance in microdensitometric tracings). Membranes isolated from bacteria frozen and incubated in $0.02 \mathrm{M}$ sodium/potassium phosphate showed well defined triple-layered profiles, with a thickness of $6.25 \pm 0.83 \mathrm{~nm}$ (Fig. $5 \mathrm{~b}$ ). Furthermore, $30 \%$ of membrane protein was lost from membranes isolated from $S$. faecium cells frozen and incubated in $0.05 \mathrm{M}$-Tris buffer, as compared to the membranes isolated from cells frozen and incubated in $0.02 \mathrm{M}$-phosphate buffer. The protein fractionation by SDS-PAGE of the two types of isolated membranes showed (Fig. 6) that the membranes isolated by autolysis of $S$. faecium cells frozen-thawed and incubated in Tris had a decreased content of proteins with $M_{\mathrm{r}}$ values above 30000 . A similar result was obtained with imidazole buffer (not shown).

\section{DISCUSSION}

In the present paper we describe lysis of $S$. faecium cells as assessed by spectrophotometry and electron microscopy. The participation of $S$. faecium autolysin was inferred from the following data. (i) Cultivation of $S$. faecium in the presence of several inhibitors of protein synthesis prevents the expression of its endogenous autolytic activity (Sayare et al., 1972). In the present work we found that pre-exposure of $S$. faecium to two such inhibitors (CAM and TC) prevented 


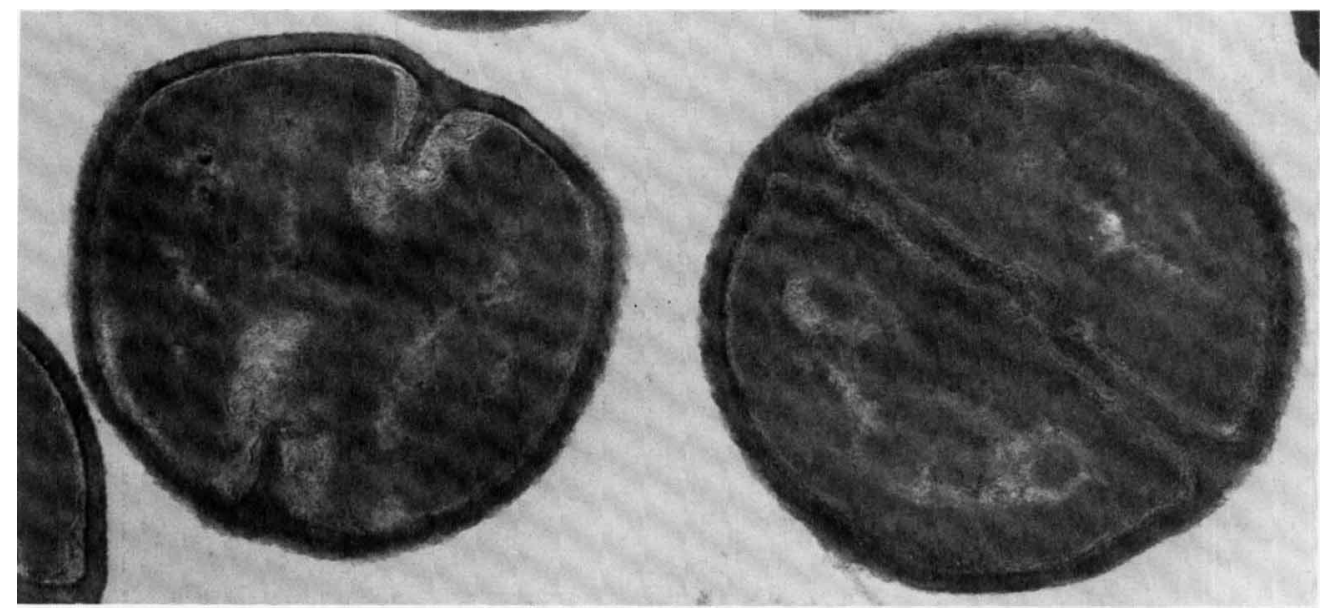

Fig. 4. Ultrastructure of mutant EC78 immediately after freezing-thawing in $0.05 \mathrm{M}$-Tris buffer, $\mathrm{pH}$ 6.8. Note the altered membranes and cell contents with absence of ribosomes. Bar, $300 \mathrm{~nm}$.

the extensive lysis that occurred with frozen cells suspended in Tris buffer. (ii) The autolytic activity of $S$. faecium can also be stopped by NBS, a molecule that promotes direct inactivation of the autolysin (Ramachandran \& Witkop, 1967; Cornett \& Shockman, 1978); such a treatment resulted in complete inhibition of the lysis of $S$. faecium frozen-thawed in Tris buffer. (iii) The use of autolytic defective-mutants derived from $S$. faecium (EC31 and EC78) provided additional evidence in favour of the role of the autolysin in the autolytic process under discussion; both mutants showed much-reduced autolysis when frozen and incubated in $0.05 \mathrm{M}$ Tris buffer, conditions that induce extensive autolysis of the wild-type strain.

We showed previously (Carvalho et al., 1984) that autolysis of $S$. faecium occurs in Tris buffer only when the cells are frozen-thawed before incubation. Now, we found that freezing-thawing of cells in Tris buffer efficiently promoted autolysis when the cells were incubated in the same buffer used for freezing-thawing. Additionally, freezing-thawing of $S$. faecium in the Tris buffers resulted in extensive $\mathrm{K}^{+}$efflux and leakage of $\mathrm{UV}$-absorbing material, and in major ultrastructural changes, including absence of ribosomes and altered membranes. Such signs of membrane damage were not observed when the bacteria were suspended in Tris buffers at room temperature. That Tris damages $S$. faecium membranes is also shown by the observation that membranes isolated after lysis of bacteria frozen and incubated in Tris buffer have an altered ultrastructure, a $30 \%$ decrease in protein content and are thinner in comparison with membranes isolated from bacteria frozen in phosphate buffer. Freezing-thawing of $S$. faecium in phosphate buffer does not result in increased autolysis, and is not accompanied by significant ultrastructural damage or efflux of $\mathrm{K}^{+}$and UV-absorbing materials.

The mechanism by which Tris buffer, at very low temperature, induces the expression of $S$. faecium cellular autolytic activity, is not presently known. Although alterations induced by freezing-thawing in the cell wall (which, in turn, would result in the uncontrolled action of the autolysin by a yet unknown mechanism) or the promotion of an alteration in the autolytic enzyme itself (for example by activating a latent form) could be involved, our data suggest than activation of $S$. faecium autolysin is secondary to the damage to the cytoplasmic membrane inflicted by freezing-thawing in Tris. Tris is not physiologically inert (Voss, 1967): for example, it increases the outer-membrane permeability of Escherichia coli by disrupting ionic interactions (Irvin et al., 1981; Schindler \& Teuber, 1978). Moreover, Alonso et al. (1979) obtained results which suggest that Tris causes an increase in the permeability of, or damage to, sarcoplasmic reticulum membranes, and found that such alterations were reproduced by replacing Tris with imidazole; their interpretation was that both molecules act through similar mechanisms. We 

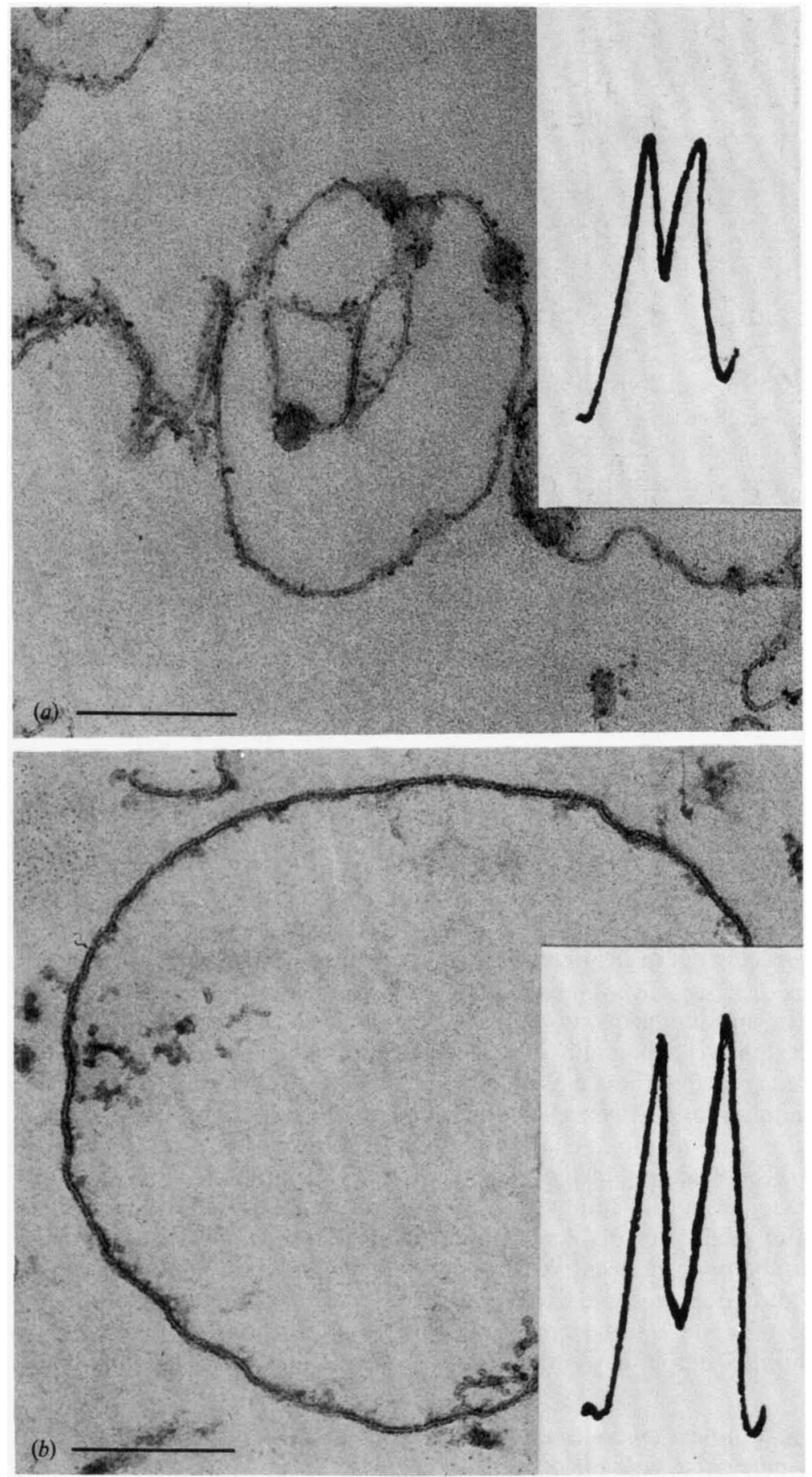

Fig. 5. Ultrastructure of membranes isolated from S. faecium. (a) Membranes isolated after autolysis in $0.05 \mathrm{M}$-Tris buffer, pH 6.8. Cells had previously been frozen-thawed in the same buffer. (b) Membranes isolated after autolysis in $0.02 \mathrm{M}$-sodium/potassium phosphate buffer, $\mathrm{pH} 6.8$, after freezing-thawing in the same buffer. Note the loose ultrastructure of the membranes isolated in Tris buffer $(a)$ in contrast with membranes isolated in phosphate buffer $(b)$. Bars, $270 \mathrm{~nm}$. Inset: densitometric tracings of membrane profiles. 
A

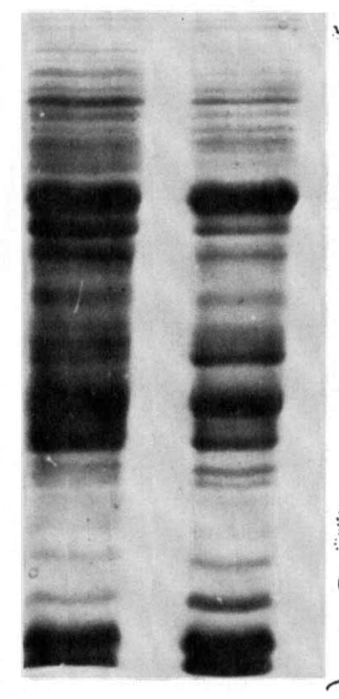

B

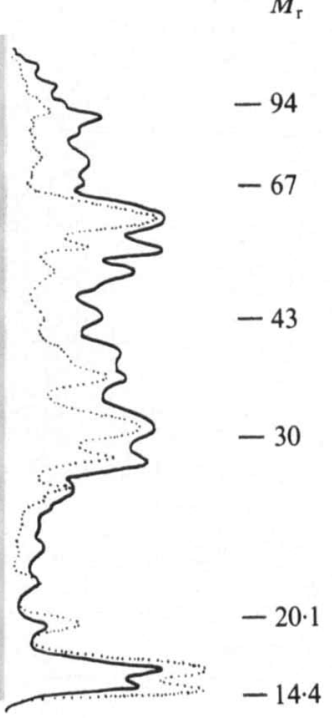

Fig. 6. SDS-PAGE of proteins from membranes isolated from $S$. faecium by autolysis. Lane A, membranes from bacteria frozen-thawed and incubated in $0.02 \mathrm{M}$-sodium/potassium phosphate buffer; lane B, membranes from bacteria frozen-thawed and incubated in $0.02 \mathrm{M}$-Tris buffer. In A and B the samples contained membrane protein obtained from an equal number of bacteria. The traces represent the bands in A ( - ) and B (......). Note that the higher amount of protein in the membranes obtained by autolysis in phosphate buffer as compared to that in the membranes obtained by autolysis in Tris buffer is mainly due to the increase in the amounts of proteins with $M_{\mathrm{r}}$ values above 30000 .

therefore compared the effects of imidazole with those of Tris. Imidazole also promoted lysis of $S$. faecium by freezing-thawing, and induced ultrastructural alterations, extensive $\mathrm{K}^{+}$efflux and significant leakage of UV-absorbing material. The effects ascribed to Tris in the present work are thus not specific but rather depend on physico-chemical characteristics common to Tris and imidazole, as discussed by Alonso et al. (1979). In contrast to these reports of the damaging actions of Tris and imidazole, in our study the alterations to $S$. faecium cells, that eventually resulted in extensive expression of endogenous autolytic activity, occurred only when the bacteria were exposed to these molecules during freezing-thawing. Jolliffe \& Doyle (1981) have shown that autolysis of Bacillus subtilis can be induced by treatments that disrupt electrical or $\mathrm{pH}$ gradients across the membrane, a mechanism that was considered by those authors to be applicable to other bacteria, including $S$. faecium. It is possible that freezing-thawing in Tris or imidazole is triggering the autolytic activity in our model through that mechanism.

The inhibitory effect of divalent cations on the expression of autolytic activity has been observed with both Gram-negative (Rayman \& MaCleod, 1975; Leduc et al., 1982; Parente \& Silva, 1984) and Gram-positive bacteria (J. Poiares \& M. T. Silva, unpublished results with $B$. subtilis). Our results are in accord in showing that addition of $10 \mathrm{mM}-\mathrm{Mg}^{2+}$ to Tris buffer partially inhibited autolysis of $S$. faecium and gave some stabilization to the cytoplasmic membrane.

The authors are grateful to Dr Teresa A. Serra for technical assistance in flame photometry and to Mrs Andrea Costa for help in the photographic work.

This work was supported in part by INIC (Lisboa) (contract 83/CEN/12).

\section{REFERENCES}

Alonso, G. L., Arrigó, D. M. \& de Fermani, S. T. (1979). Effect of Tris (hydroxymethyl) aminomethane on the isolated sarcoplasmic reticulum vesicles. Archives of Biochemistry and Biophysics 198, 131-136.

Carson, D. D. \& Daneo-MoORE, L. (1979). Effects of fatty acids on the lysis of Streptococcus faecalis. Journal of Bacteriology 141, 1122-1126.

Carvalho, M. E., Gonçalves, M. H. \& Silva, M. T. 
(1984). A turbidimetric and electron microscopy study of the effects of several parameters on the lysis of Streptococcus faecalis by lysozyme. Canadian Journal of Microbiology 30, 905-915.

Cornett, J. B. \& Shockman, G. D. (1978). Cellular lysis of Streptococcus faecalis induced with Triton X100. Journal of Bacteriology 135, 153-160.

Irvin, R. T., MacAlister, T. J. \& Costerton, J. W. (1981). Tris (hydroxymethyl) aminomethane buffer modification of Escherichia coli outer membrane permeability. Journal of Bacteriology 145, 1397-1403.

Jolliffe, L. K. \& Doyle, R. J. (1981). The energized membrane and cellular autolysis in Bacillus subtilis. Cell 25, 753-763.

Leduc, M., Kasra, R. \& van Heijenoort, J. (1982). Induction and control of the autolytic system of Escherichia coli. Journal of Bacteriology 152, 26-34.

LUFT, J. H. (1961). Improvements in epoxy resin embedding methods. Journal of Biophysical and Biochemical Cytology 9, 409-412.

Parente, A. M. \& Silva, M. T. (1984). Ultrastructural aspects of autolysis of Pseudomonas fluorescens induced by osmotic shock. Journal of General Microbiology 130, 1459-1470.

PoOLEy, H. M. (1976). Turnover and spreading of old wall during surface growth of Bacillus subtilis. Journal of Bacteriology 125, 1127-1138.

Pooley, H. M. \& Karamata, D. (1984). Genetic analysis of autolysin-deficient and flagellaless mutants of Bacillus subtilis. Journal of Bacteriology 160, 1123-1129.

Pooley, H. M., Shockman, G. D., Higgins, M. L. \& Porres-Juan, J. (1972). Some properties of two autolytic-defective mutants of Streptococcus faecalis ATCC 9790. Journal of Bacteriology 109, 423-431.

Ramachandran, L. K. \& WitkoP, B. (1967). NBromosuccinimide cleavage of peptides. Methods in Enzymology 11, 238-299.

Ranhand, J. M., Leonard, C. G. \& Cole, R. M. (1971). Autolytic activity associated with competent group H streptococci. Journal of Bacteriology 106, 257-268.

RaYMAN, M. K. \& MACleOd, R. A. (1975). Interaction of $\mathrm{Mg}^{2+}$ with peptidoglycan and its relation to the prevention of lysis of marine pseudomonads. Journal of Bacteriology 122, 650-659.

Rogers, H. J. (1979). The function of bacterial autolysins. In Microbial Polysaccharides and Polysaccharases, pp. 237-268. Edited by R. C. W. Berkeley, G. W. Gooday \& D. C. Ellwood. London \& New York: Academic Press.

RYter, A. \& Kellenberger, E. (1958). Etude au microscope électronique de plasmas contenant de l'acid deoxyribonucléique. I. Les nucléoides de bactèries en croissance active. Zeitschrift für Naturforschung 13B, 597-605.

Sayare, M., Daneo-Moore, L. \& Shockman, G. D. (1972). Influence of macromolecular biosynthesis on cellular autolysis in Streptococcus faecalis. Journal of Bacteriology 112, 337-344.

SChindler, P. R. G. \& Teuber, T. (1978). Ultrastructural study of Salmonella typhimurium treated with membrane-active agents: specific reaction of dansyl chloride with cell envelope components. Journal of Bacteriology 135, 198-206.

Shockman, G. D. (1965). Symposium on the fine structure and replication of bacteria and their parts. IV. Unbalanced cell wall synthesis and cell wall thickening. Bacteriological Reviews 29, 345-358.

Shockman, G. D., Conover, M. J., Kolb, J. J., Philips, P. M., Riley, L. S. \& ToenNies, G. (1961). Lysis of Streptococcus faecalis. Journal of Bacteriology 81, 36-43.

Shockman, G. D., Pooley, H. M. \& Thompson, J. S. (1967). Autolytic enzyme system of Streptococcus faecalis. III. Localization of the autolysin at the sites of cell wall synthesis. Journal of Bacteriology 94, 1525-1530.

Shungu, D. L., Cornett, J. B. \& Shockman, G. D. (1979). Morphological and physiological study of autolytic-defective Streptococcus faecium strains. Journal of Bacteriology 138, 598-608.

Silva, M. T., Santos-Mota, J. M., Melo, J. V. C. \& Carvalho Guerra, F. (1971). Uranyl salts as fixatives for electron microscopy. Study of the membrane ultrastructure and phospholipid loss in bacilli. Biochimica et biophysica acta 233, 513-520.

Venable, J. H. \& Coggeshall, R. (1965). A simplified lead citrate stain for use in electron microscopy. Journal of Cell Biology 25, 407-408.

Voss, J. G. (1967). Effects of organic cations on the Gram-negative cell wall and their bactericidal activity with ethylenediaminetetra-acetate and surface active agents. Journal of General Microbiology 48, 391-400. 